\title{
PENGUATAN MODERASI BERAGAMA MELALUI PEACE EDUCATION GUNA MEWUJUDKAN JURNALISME DAMAI
}

\author{
Sidik Permana ${ }^{1}$, Mursyid Setiawan ${ }^{2}$ \\ ${ }^{1,2}$ Universitas Pendidikan Indonesia \\ ${ }^{1}$ sidiksipengelana@gmail.com \\ 2mursyidsetiawan14@gmail.com
}

\begin{abstract}
Diversity is a necessity that cannot be separated from human life. In order to maintain the harmony of life in this diversity, peace must be fought for by all parties, one of which is through peace education. The goal of peace education is to produce people who are wise and able to position themselves through a process of strengthening moderation. This research is based on Johan Galtung's thoughts with his concept of "peace" and "violence" which is a reference for the creation of resolution and post-conflict. This research uses qualitative methods with literature studies through various reference sources, both from books, journals, official websites, and so on. The implementation of Johan Galtung's thoughts in peace education is expected to foster self-discipline and produce individuals who are not only able to interpret peace, create conflict resolution, are able to position themselves in every problem, but also lead to a transformative and lasting peace, without ignoring the presence of violence that will lead to peace. always present as peace is born. This is what is currently needed, especially for the world of journalism which is closely related to the flow and battle of information. With this peace education, it is hoped that a journalist can make decisions to produce journalistic work that is able to reconcile, be balanced, and even become a solution effort to produce transformation and conflict resolution.
\end{abstract}

Keywords: Peace Education, Peace, Violence, Conflict

Abstrak - Keberagaman merupakan keniscayaan yang tidak bisa dipisahkan dari kehidupan manusia. Guna menjaga keharmonisan hidu dalam keberagaman tersebut, perdamaian harus diperjuangkan semua pihak, salah satunya melalui peace education (pendidikan damai). Tujuan dari peace education melahirkan insan yang bijaksana dan mampu memposisikan diri melalui proses penguatan moderasi. Penelitian ini bertitik tolak pada pemikiran Johan Galtung dengan konsep "peace" dan "violence"-nya yang menjadi rujukan bagi terciptanya resolusi dan pasca konflik. Riset ini menggunakan metode kualitatif dengan studi pustaka melalui berbagai sumber referensi, baik dari buku, jurnal, laman resmi, dan sebagainya. Implementasi pemikiran Johan Galtung dalam peace education ini diharapkan menumbuhkan kebijaksanaan diri dan melahirkan individu yang tidak hanya mampu memaknai kedamaian, menciptakan resolusi konflik, mampu memposisikan diri dalam setiap problematika, tetapi juga membawa ke arah kedamaian yang transformatif dan abadi, tanpa mengabaikan kehadiran kekerasan yang akan selalu hadir seiring perdamaian terlahir. Hal itulah yang saat ini dibutuhkan, terlebih bagi dunia jurnalistik yang erat kaitannya dengan arus dan pertarungan informasi. Dengan peace education ini, diharapkan seorang jurnalis dapat mengambil keputusan untuk menghasilkan karya jurnalistik yang mampu mendamaikan, berimbang, bahkan menjadi upaya solutif untuk menghasilkan transormasi dan resolusi konflik.

Kata Kunci: Pendidikan Damai, Damai, Korban, Konflik

\section{PENDAHULUAN}

Keberagaman di Indonesia adalah sebuah anugerah, maka dari itu perlu dirawat dan dijaga. Yaqut Cholil Qoumas, Menteri Agama Republik Indonesia, sebagaimana dikutip dari laman Lembaga Ketahanan Nasional RI (2021), mengungkapkan bahwa "Keragaman adalah kehendak Tuhan." Ia menambahkan bahwa Tuhan memang menghendaki manusia beragam dan tidak sama semua. Oleh karena itu, guna membangun rasa saling toleransi terhadap perbedaan itu, dialog dan solidaritas keagamaan harus diwujudkan. 
Akan tetapi, rasa ketidakpercayaan yang berlandaskan perbedaan antar satu sama lain tidak bisa dihindari. Tilaar (dalam Ansori, 2019, hlm. 111) mengatakan bahwa budaya yang beragam (multikultural) di samping membawa nilai positif di dalam kehidupan juga dapat membawa kepada pertikaian dan konflik.

Dalam sebuah studi dari Pusat Pengkajian Islam dan Masyarakat (HLMIM) Universitas Islam Negeri (UIN) Syarief Hidayatullah Jakarta (2021), di tahun 2020 bertajuk "Kebinekaan di Menara Gading: Toleransi Beragama di Perguruan Tinggi” mengungkapkan tingkat toleransi di kalangan mahasiswa dari beragam latar kelompok keagamaan, seperti Islam, Katolik, Protestan, Hindu, Buddha, Konghucu dan aliran kepercayaan lainnya.

Dalam studi yang dilakukan di 34 provinsi itu, didapatkan fakta bahwa tingkat toleransi beragama di lingkungan Perguruan Tinggi (PT) di 92 PT dari 100 PT yang tersebar di seluruh Indonesia tergolong sangat tinggi dengan persentase $20 \%, 69,83 \%$ bertoleransi agama tinggi, $24,89 \%$ tergolong rendah, dan 5,27\% lainnya masuk kategori sangat rendah.

Riset lainnya datang dari Pusat Penelitian dan Pengembangan (Puslitbang) Kementerian Agama Republik Indonesia yang merilis Indeks Kerukunan Umat Beragama (KUB) 2019. Sebagaimana dikutip dari laman resmi Kementerian Agama (2019), indeks KUB Indonesia di tahun 2019 berada di atas rata-rata nasional dengan skor poin 73,83 dari rentang 0-100, atau masuk kategori "Rukun Tinggi". Tentu saja, kerukunan semacam ini harus dipertahankan, bahkan ditingkatkan. Tetapi, Soerjono Soekanto (2006, hlm. 65) menyebutkan bahwa bila muncul interaksi antara dua kelompok masyarakat (etnis), kemungkinan yang terjadi adalah membentuk kerjasama, konflik, dan akomodasi. Jadi, sekalipun tingkat toleransi sangat tinggi, namun kehadiran sikap sebaliknya memang tidak bisa dihilangkan.

Kerap kali keharmonisan yang telah dibangun itu harus pudar akibat ulah segelintir orang yang merusak ketertiban, bahkan cenderung menggunakan, membesarkan dan menggiring opini publik agar larut dalam konflik/isu intoleran dan perpecahan, hingga berdampak kepada hilangnya ketentraman hidup. Walaupun pada hakikatnya, konflik akan selalu ada, namun level konflik itulah yang mesti dikhawatirkan. Ketidaktahuan dan keterbatasan seseorang, khususnya penerimaan terhadap "perbedaan" menjadi penyebab maraknya konflik yang diakibatkan oleh sikap intoleran. KH. Abdurrahman Wahid atau dikenal Gus Dur, sebagaimana ditulis di laman resmi Nahdlatul Ulama (2019), mengungkapkan jika konflik keagamaan bermula dari adanya ketidaktahuan dan pendangkalan pemahaman agama para pemeluknya. Ia melanjutkan jika formalisasi ajaran agama layaknya hukum positif pun turut memicu konflik keagamaan, khususnya di Indonesia.

Balai Litbang Agama Jakarta (BLAJ) Balitbang Diklat Kementerian Agama RI (2019), pernah merilis sebuah penelitian. Dalam riset bertajuk "Sistem Peringatan dan Respon Dini Konflik Keagamaan Fase II: Variasi Efektivitas Respons Dini Konflik Keagamaan", Rudi Harisah Alam bersama timnya menemukan paling tidak ada enam jenis konflik keagamaan yang mendominasi di Indonesia, di antaranya: 1) Moral; 2) Sektarian; 3) Komunal; 4) Politik/kebijakan; 5) Terorisme; dan 6) lainnya. Dan, dari jenis konflik keagamaan tersebut, sejak tahun 20172019, setidaknya ada satu kasus konflik terkait isu terorisme, 14 kasus isu 
komunal (antaragama), dan 12 terkait masalah sektarian (intraagama).

Kasus intoleran yang pernah terjadi di Indonesia, misalnya penolakan penggunaan rumah warga menjadi Gereja untuk Jemaat Advent Hari Ketujuh di Kecamatan Makasar, Jakarta Timur. Lalu, penolakan yang sama terjadi pada rumah ibadah GKI (Gereja Kristen Indonesia) Yayasan Wisesa Wicaksana di Jakarta Selatan, protes warga terhadap gereja damai milik umat Katolik di Jakarta Barat, dll. Fenomena kemajemukan bagaikan pisau bermata dua, di satu sisi memberi dampak positif tetapi pada sisi lain memberi dampak negatif (Ansori, 2019, hlm. 111).

Upaya dalam menanggulangi permasalahan moderasi beragama ini sering mendapat tantangan, khususnya dari media massa yang kerap menginformasikan berita dengan "bombastis" dan cenderung memanfaatkan situasi dengan judul headline yang kerap provokatif, ambigu, dan tidak komprehensif. Padahal, sebagai seorang jurnalis, informasi yang diberitakan harus memuat konten yang menyejukan dan mencerdaskan, sekalipun isu yang diangkat sangat sensitif, bukan demi tarikan konsumen pembaca yang mudah menarik kesimpulan dan emosional. Kebutuhan akan jurnalisme damai sangatlah diperlukan di sini. Ishwara (dalam Andarini, 2014, hlm. 89) menjelaskan bahwa sejatinya banyak media berprinsip jika konflik punya nilai berita yang "tinggi", khusunya konflik fisik, karena itulah perang, pembunuhan, kekerasan fisik dan lainnya ditempatkan di halaman muka.

Belum termasuk kekuatan media massa yang bergerak di dunia digital yang kian masif dan luas, sehingga sulit mencerna dan mengontrol karya jurnalistik yang disampaikan, baik secara provokatif atau damai. Heidi Campbell dalam bukunya
When Religion Meets New Media (Campbell, 2010, hlm. 70) menjelaskan konsep Religious-Social Shaping of Technology, yaitu bahwa dampak era digital terhadap cara beragama masyarakat, di antaranya yang paling terasa adalah pudarnya afiliasi terhadap lembaga keagamaan, bergesernya otoritas keagamaan, menguatnya individualisme, dan perubahan dari pluralisme menjadi tribalisme.

Sebagai contoh, keterlibatan media massa yang jauh dalam mengimplementasikan jurnalisme damai. Berdasarkan penelitian Rindang Senja Andarini (2014, hlm. 89) yang dituangkan dalam jurnal berjudul "Jurnalisme Damai dalam Pemberitaan Ahmadiyah pada Harian Jawa Pos", didapati bahwa secara analisis struktur sintaksis (headline, lead, latar informasi, sumber, dan penutup) menunjukkan beberapa judul berita yang diangkat Jawa Pos cukup frontal dengan menampakkan sikapnya yang kontra dan tidak berimbang terhadap persoalan Ahmadiyah. Hal itu terlihat pada headline salah satu berita berjudul "Gubernur Jatim Larang Aktivitas Ahmadiyah, "SBY Minta Ahmadiyah Berhenti", "Istana Ditarget 10 Hari untuk Bubarkan Ahmadiyah. Bahkan, dalam beberapa kasus, terdapat pemberitaan harian yang tidak konsisten antara judul yang diangkat dan lead yang dituliskan, seperti pada Edisi 18 Februari 2011 mengenai hasil penyelidikan, di mana Jawa Pos mengangkat berita berjudul "Polisi Sebut Kiai Ujang Dalang Rusuh Ahmadiyah", akan tetapi informasi yang dituliskan pada latar berita justru mengenai unjuk rasa ormas yang menuntut pembubaran Ahmadiyah.

Permasalahan semacam itu bisa dihindari bila mana para jurnalis menerapkan prinsip "jurnalisme damai". Dalam hal ini, Jake Lynch, sebagaimana dikutip dari laman Indonesia.id (2017), memaparkan bahwa jurnalisme damai atau peace 
journalism merupakan situasi ketika para editor dan reporter membuat pilihan mengenai apa dan bagaimana melaporkannya, serta menciptakan kesempatan bagi masyarakat untuk mempertimbangkan dan menilai tanggapan non-kekerasan terhadap konflik.

Dikutip dari laman Indonesiabaik.id (2017), Arif Zaini mengungkapkan bahwa pendekatan jurnalisme seperti yang dicetuskan John Galtung, Rune Ottosen, Wilhem Kempt, dan Maggie O'Kane tidak lain berupaya untuk menghindari atau mencegah kekerasan di masyarakat dengan memperhatikan laporan suatu kejadian dengan lebih menyeluruh, berimbang, dan akurat dengan didasarkan pada informasi. Prinsip jurnalisme yang diusung diharapkan menjadi jembatan untuk terciptanya perdamaian. Artinya, seluruh pihak, baik dalam skema penyusunan informasi dalam pemberitaan hingga sampai kepada pembaca, terlibat dan bertanggung jawab menyuguhkan karya jurnalistik yang berkualitas dan ditujukan demi perdamaian.

Juditha (2016, hlm. 99-100), dalam penelitiannya pernah mengungkapkan beberapa media massa di Indonesia berupaya untuk mengamalkan jurnalisme damai, salah satunya Tempo.co. Dalam hal ini, sebesar $86,49 \%$ konten media Tempo.co dari 37 berita mengenai peristiwa Tolikara yang dirilis mengarah pada orientasi perdamaian.

Jurnalisme damai yang diupayakan tersebut memiliki kesamaan dengan komitmen Kementerian Agama, sebagaimana tertuang dalam Surat Edaran tanggal 29 Oktober 2019, untuk menjadikan moderasi beragama sebagai bagian dari landasan berpikir, bersikap, rumusan kebijakan dan program di seluruh stakeholder Kementerian Agama (Anon, 2020, hlm. 2).
Oleh karena itu, membangun budaya toleran dan moderasi bergama menjadi berguna untuk meminimalisir konflik multidimensional tersebut, salah satu caranya melalui peace building yang dapat diimplementasikan dengan peace education. Dalam sebuah penelitian berjudul "Menciptakan Perdamaian Melalui Pendidikan Perdamaian di Sekolah", Wulandari (dalam Atmanto, 2017, hlm. 157) menjelaskan bahwa pendidikan perdamaian sejatinya akan lebih baik bila dikomunikasikan melalui perantara mata pelajaran tertentu dan tersendiri atau bukan sekadar nilai yang hanya dikembangkan implisit (hidden curriculum). Tujuan pendidikan damai sendiri adalah agar orang dapat belajar untuk saling memahami satu sama lain dan mengasah kebijaksanaannya dalam menghadapi perbedaan. Sehingga, dapat mewujudkan dunia yang penuh dengan keadilan, tanpa kekerasan, saling menjunjung tinggi HAM, minim konflik, minim eksploitasi satu sama lain, dan membina kehidupan yang penuh damai (Atmanto, 2017, hlm. 157).

Inilah yang menjadi alasan utama tim peneliti untuk mencari penyelesaian masalah dari maraknya tindakan intoleran. Melalui pendidikan damai, khususnya yang diimplementasikan di perguruan tinggi, diharapkan dapat membentuk pola pikir mendamaikan. Bahkan, itu akan menjadi lebih baik bila diimplementasikan dalam jurnalisme damai, baik dalam perspektif profesional maupun kita sebagai masyarakat biasa. Artinya, penelitian ini bertujuan agar pembaca dapat menjadi jurnalis damai, baik untuk diri Anda sendiri dan masyarakat, melalui peace building yang dihidupkan dalam pendidikan damai (peace education). Hal yang terpenting adalah bagaimana pendidikan damai ini bisa diterapkan di institusi pendidikan, sehingga menghasilkan manusia yang bijak dan mampu menerima perbedaan. 


\section{METODE PENELITIAN}

Metode yang digunakan dalam penelitian ini adalah kualitatif dengan pendekatan studi literatur. Penelitian kualitatif merupakan metode-metode untuk mengeksplorasi dan memahami makna yang-oleh sejumlah individu atau sekelompok orang-dianggap berasal dari masalah sosial atau kemanusiaan (Creswell, 2014, hlm. 4)

Dalam peninjauan literatur, definisi formal itu tidak ada yang umumnya digunakan untuk menerapkan model kodifikasi, atau spesifikasi apapun untuk komponen/variabelnya (Espitia, et al., 2016, hlm. 1111). Dengan demikian, para peneliti tidak perlu membebani diri dengan menyusun kembali sebuah definisi secara formal, karena hal itu justru telah diakomodir oleh literatur yang telah tersedia sebagai bahan rujukan. Bisa dikatakan, riset berbasis pustaka umumnya memanfaatkan sumber dari "perpustakaan" untuk memperoleh data penelitiannya (Zed, 2018, hlm. 1-2). Dengan demikian, peneliti bisa melakukan risetnya tanpa perlu ke lapangan, secara harfiah. Mestika Zed (dalam Supriyadi, 2016, hlm. 85) menjelaskan bila studi pustaka atau kepustakaan secara sederhana diartikan sebagai serangkaian kegiatan berkaitan dengan metode pengumpulan data, membaca dan mencatat serta mengolah bahan penelitian berbasis pustaka (literatur).

Studi kepustakaan sendiri, menurut Sugiyono (2013, hlm. 291) berhubungan dengan kajian teoritis dan referensi lain yang terkait dengan nilai, budaya, dan norma yang berkembang pada situasi sosial yang diteliti. Ia melanjutkan, bahwa terdapat tiga kriteria pengembangan teori yang digunakan sebagai pijakan dalam penelitian studi literatur ini, diantaranya: 1) Relevansi, relevansi yaitu kesinambungan teori yang dikemukakan dengan permasalahan yang diteliti; 2) Kemutakhiran, yaitu kebaruan (novelty) sebuah teori atau referensi rujukan; dan 3) Keaslian yang berkaitan dengan keaslian sumber, yaitu penggunaan sumber aslinya dalam mengemukakan teori.

Alasan peneliti menggunakan studi literatur, selain dari beberapa hal yang telah disampaikan di atas, sebagaimana yang diungkapkan oleh Mestika Zed (2018, hlm. 4-5) dalam bukunya berjudul Metode Penelitian Kepustakaan, yaitu: 1) Peneliti dihadapkan langsung dengan teks (nash) atau data angka dan bukan dengan pengetahuan langsung dari lapangan atau saksi-mata (eyewitness) berupa kejadian, orang atau benda-benda lainnya; 2) Data pustaka bersifat "siap pakai" (readymade); 3) Data pustaka merupakan sumber sekunder; dan 4) Kondisi data pustaka tidak dibatas oleh ruang dan waktu. Hal itu memudahkan tim peneliti, sekaligus menjadi pembanding antar referensi yang menjadi rujukan. Tidak hanya seputar penggalian data, studi literatur menjadi jembatan bagi peneliti untuk mencari komparasi dari keterbatasan ilmu pengetahuan yang dimiliki tim riset dan realitas di lapangan. Wertz, dkk (2011, hlm. 88) menjelaskan jika, "A critical review of the literature allows researchers to identify such a gap between what is known and the portion of reality that exceeds our knowledge". Dan, akhirnya studi literatur membantu peneliti untuk menjelaskan jawaban/hasil yang muncul di sana (Dawson, 2002, hlm. 19).

\section{HASIL DAN PEMBAHASAN}

\section{Subjek dalam Perdamaian dan Kekerasan}

Marthin Luther King dalam sebuah kesempatan pernah mengungkapkan, "True peace is not merely the absence of 
tension: it is the presence of justice". Kenyataannya, menggambarkan kedamaian seperti yang selama ini dipikirkan-diupayakan bersama-tidak sesederhana yang dipikirkan. Perbendaharaan kamus bisa saja tidak mewakili keseluruhan maksud, termasuk dalam mewakili makna damai. Beberapa menilai bahwa "damai" atau "perdamaian" adalah sesuatu yang cukup sakral dan diidamkan. Tidak mengherankan jika perdamaian sendiri adalah perjuangan untuk mencapai sesuatu apa yang dimaksud dengan "meminimalisir hadirnya ketakutan dalam hidup. Ursula Franklin (dalam Machali, 2013, hlm. 43) berpendapat bahwa damai bukan hanya sekadar tidak adanya perang, tetapi terciptanya keadilan dan hilangnya rasa takut dalam diri individu dan masyarakat.

Bila dicermati kembali, hal-hal semacam rasa takut, perang, ketidakadilan, dan persoalan kemerdekaan hak manusia lainnya, adalah segelintir persoalan "kekerasan" yang menjadi fokus perhatian dalam peace building. "That peace has something to do with 'absence of violence' is so widespread as an idea that any concept of peace research would have to accommodate this notion" (Galtung, 1985, hlm. 145). Tidak bisa dipungkiri, kekerasan sejatinya antitesis perdamaian akan selalu terlahir dan berdampingan, namun itu bukan berarti tidak bisa diminimalisir. Johan Galtung (dalalm Navarro-Castro \& Nario-Galace, 2010, hlm. 18) menjelaskan bahwa perdamaian adalah merupakan kondisi ketiadaan kekerasan, tidak hanya yang terlahir dari pribadi maupun langsung, tetapi juga kekerasan yang timbul dari struktur sosial yang tidak langsung.

Masing-masing kekerasan yang dimaksud Johan Galtung (dalam Eriyanti, 2017, hlm. 2), diistilahkan sebagai "segitiga kekerasan". Itu merupakan gagasan cemerlang dalam mengidentifikasi keberadaan dan bentukbentuk kekerasan yang ada. Segitiga kekerasan yang dimaksud, di antaranya: 1) Kekerasan langsung, yaitu bentuk kekerasan yang dilihat langsung dan secara nyata dilakukan pelakunya; 2) Kekerasan struktural, yaitu kekerasan yang lahir dari adanya struktur sosial yang dibangun, di mana ia akan melukai kebutuhan dasar manusia, tetapi tak ada pelaku langsung yang bisa dimintai pertanggungjawaban; dan 3) Kekerasan kultural, yang merupakan legitimasi atas kekerasan struktural maupun kekerasan langsung secara budaya yang dibentuk. Semua itu umumnya lahir, berkembang, dan terus bertahan di kehidupan seseorang dan "diresmikan" secara sosial. Semuanya cukup membuat kita bertanyatanya mengenai keabsahan perdamaian yang diperjuangkan.

Kekerasan sejatinya penghalang terhadap bentuk aktualisasi manusia, sedangkan bentuk aktualisasi diri adalah bagian dari kemerdekaan manusia yang kerap bersinggungan dengan kepentingan aktualisasi orang lain. Namun, penghalangan yang dimaksud Johan Galtung, menurut Muchsin (dalam Eriyanti, 2017, hlm. 3) dapat dihindarkan, sehingga sebenarnya kekerasan itu juga bisa dihindari jika penghalang itu disingkirkan. Bila masukan persoalan moderasi yang selama ini menjadi persoalan, maka penghalang yang dimaksud adalah dapat berupa kejumudan pikiran dan rendahnya kemampuan dalam menganalisis kondisi sosial kontemporer, khususnya mengenai lemahnya seseorang dalam mengambil dan memposisikan perannya sebagai insan pembentuk perdamaian. Johan Galtung (dalam Eriyanti, 2017, hlm. 3) menegaskan, "Kekerasan adalah setiap kondisi fisik, emosional, verbal, institusional, struktural atau spiritual, juga perilaku, sikap, kebijakan atau kondisi yang melemahkan, mendominasi atau 
menghancurkan diri kita sendiri dan orang lain." Dengan demikian, perhatian penting sekaligus utama akan tertuju pada subjek individu.

Problem utama dalam permasalahan sosial kebudayaan selalu bermuara pada kehadiran manusia dan usahanya untuk mewujudkan sesuatu di kehidupan bermasyarakat. Dalam hal ini, perdamaian yang berusaha diwujudkan pun pada hakikatnya bergerak pada usaha manusia untuk menciptakan ketentraman hidup, dan karena itulah manusia menjadi subjek vital, baik secara pribadi, antara sesama, maupun relasi struktural. Meskipun struktur itu sendiri diciptakan oleh mereka, bila didasarkan pada prinsip perdamaian maka struktur yang dihasilkan akan menuju pada perdamaian itu sendiri. Hal itu senada dengan ungkapan, "The greatest resurce for bulding a culture of peace are the people themselves, for it is through them that peaceful relationshios and structures are created" (Navarro-Castro \& NarioGalace, 2010, hlm. 27).

\section{Peace Education dalam Membentuk Kebijaksanaan}

Pola pemikiran yang damai ini tidak begitu saja terbentuk, bahkan komitmen saja tidak cukup, paling tidak ada upaya yang terstruktur dan konsisten untuk menanamkan pemikiran damai ini. Salah satunya melalui pendidikan damai (peace education). Pendidikan damai ini bekerja untuk mempromosikan budaya damai, di mana pada dasarnya peace education bergerak secara transformatif (NavarroCastro \& Nario-Galace, 2010, hlm. 27). Artinya, pendidikan damai ini bertujuan untuk menumbuhkan pengetahuan, keterampilan, sikap, dan nilai dalam mengubah cara berpikir, sikap, dan perilaku yang cenderung destruktif atau memperburuk konflik. Transformatif menuju perdamaian ini menjadi landasan bagi pengimplementasian pendidikan, sehingga siapa pun, khususnya jurnalis, mampu memandang dunia dengan jauh lebih baik dan konform.

Meskipun begitu, hingga saat ini kita masih belum menyepakati bersama, sejauh mana peace education/pendidikan damai ini bisa diterima secara definitif, bahkan "damai" itu sendiri memiliki beragam perspektif dan aksi dalam menggambarkan. Namun, satu hal yang bisa kita terima sejauh ini adalah peace education mendambakan subjek yang dengan tulus berhasil mewujudkan ketentraman, berhubungan, dan berinteraksi hidup, sejalan dengan apa yang kita kenal sebagai "ketiadaan kekerasan". Dalam hal ini, Thapa, dkk., (2010, hlm. 17) berpikir demikian, bahwa pendidikan perdamaian ini merupakan konsep yang agak amorf (tanpa wujud) yang dapat dipahami dan dipraktikkan secara berbeda pada tiap negara dan bangsa, atau dari budaya ke budaya lainnya, di mana hal terpenting yang tidak boleh tidak ada adalah prosesnya di mana anggota masyarakat diharapkan menumbuhkan keyakinan, sikap dan perilaku yang sejalan dengan gagasan non-kekerasan.

Memang, tidak mudah untuk menyeimbangkan frekuensi tentang makna damai bagi semua orang, terlebih menjadi landasan dalam menciptakan konten pendidikan yang mendamaikan, tapi semua (harus) sepakat bahwa itu harus dilakukan dan tidak membuangbuang waktu dengan definisi semata. Haavelsrud (dalam Webel \& Galtung, 2007, hlm. 280) berpandangan perlu adanya diskusi bersama berkenaan dengan pemahaman perdamaian sehingga menjadi landasan guna menyusun substansi peace education. Diskusi tersebut menemukan tiga perspektif, yaitu: 1) Perdamaian harus dilihat apa adanya, bukan tentang "apa"-nya. Hal ini, sebagaimana pandangan Johan Galtung, yang memandang kedamaian adalah lawan dari kekerasan, baik dalam 
bentuknya yang langsung, struktural, maupun kultural; 2) Perdamaian memiliki hubungan dengan berbagai tingkatan, seperti individu hingga global; dan 3) Perdamaian dipandang sebagai struktur yang relatif permanen di mana ia tidak hanya mampu meningkatkan nilainilai perdamaian tetapi menghidupan proses interaksi di dalam struktur yang bisa jadi lebih atau kurang damai, atau dilingkupi kekerasan.

Sebagai contoh, pandangan Luigi da Porto (Aji \& Indrawan, 2019, hlm. 72) mengenai siklus perdamaian and konflik cukup menarik perhatian. Menurutnya, siklus keduanya bergerak dari perdamaian yang mendatangkan kemakmuran, lalu menuju ke kemakmuran yang mendatangkan kebanggaan, kebanggaan mendatangkan amarah, amarah mendatangkan perang, perang mendatangkan kemiskinan, kemiskinan mendatangkan kemanusiaan, kemanusiaan mendatangkan perdamaian. Bisa dikatakan, menurutnya kedamaian akan (selalu) menghasilkan perang, dan itu artinya kekerasan.

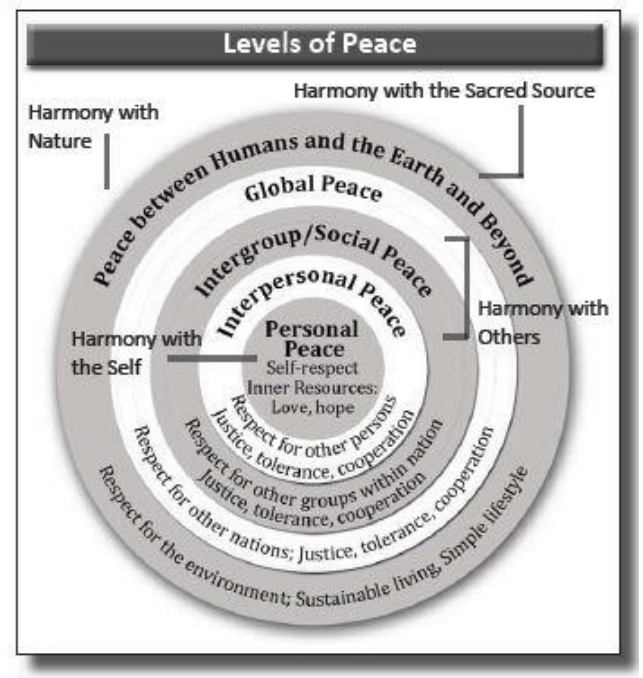

Gambar 1. Level Peace

Sumber: (Navarro-Castro \& NarioGalace, 2010, hlm. 21)
Berkenaan dengan hal itu, prinsip pendidikan damai sendiri adalah bagaimana seorang individu dapat mengembangkan kedamaian dalam dirinya sendiri. Sama seperti pembahasan sebelumnya, ranah di luar dirinya akan bisa saja menghasilkan perdamaian yang berarti bila seorang individu tidak mengabaikan prinsip perdamaian dalam pikirannya, sikapnya, dan tindakannya, karena itu menjadi cikal bakal membentuk hal serupa di luar dirinya. Kekerasan yang lahir-Johan Galtung ungkap segitiga kekerasan-baik secara langsung, struktural dan budaya, justru tidak terlepas dari gagalnya individu untuk menginternalisasi nilai perdamaian yang dimaksud. Hal yang jauh lebih bahaya adalah bila jiwa-jiwa destruktif itu terefleksikan dalam variabel di luar dirinya. Oleh karena itu, pada gambar 1 itulah, gambaran yang akan menjadi target peace education guna mewujudkan manusia yang damai, di mana itu akan senantiasa berkembang hingga menjalin relasi kedamaian dengan pihak non humanistik seperti alam, bumi, lingkungan, dan sebagainya.

Ada hal menarik yang Johan Galtung (1981, hlm. 195) ungkapkan terkait persoalan konsep kedamaian yang banyak diperbincangkan. Menurutnya, bila "ketenangan pikiran" dimasukkan dalam konsep perdamaian, dan ini diartikan sebagai identitas, kedekatan dengan diri sendiri dan orang lain, masyarakat dan alam, dengan sesuatu di atas dirinya (membuatnya lebih kaya daripada konsep kesehatan mental yang dibangun pada gagasan kesehatan jiwa pada seseorang), maka segala sesuatu yang mengurangi atau menghambat identitas bisa disebut sebagai kekerasan. Bahkan, internalisasi non fisikal semacam ini akan jauh lebih rumit karena melibatkan sesuatu yang tak nampak dan ada di dalam benak manusia. Jadi, sudah kah pikiran dan jiwa damai? 
Sejauh ini, pendidikan damai memiliki ragam bentuk dalam tataran praktiknya, semisal pendidikan perlucutan senjata, Hak Asasi Manusia (HAM), pendidikan berwawasan global/internasional, pendidikan resolusi konflik, pendidikan multikultural, pendidikan untuk memahami dunia internasional, pendidikan lintas agama, pendidikan gender dan nondiskriminatif, pendidikan kemajuan (development), dan pendidikan berbasis lingkungan. (Navarro-Castro \& Nario-Galace, 2010, hlm. 39). Terlepas dari bentuk apapun, peace education, begitu juga dengan metode pembelajaran yang lainnya, perlu melibatkan berbagai komponen yang secara harfiah proses pendidikan berikrar pada pengembangan kemampuan kognitif, afektif, dan aktif (psikomotor-motorik).

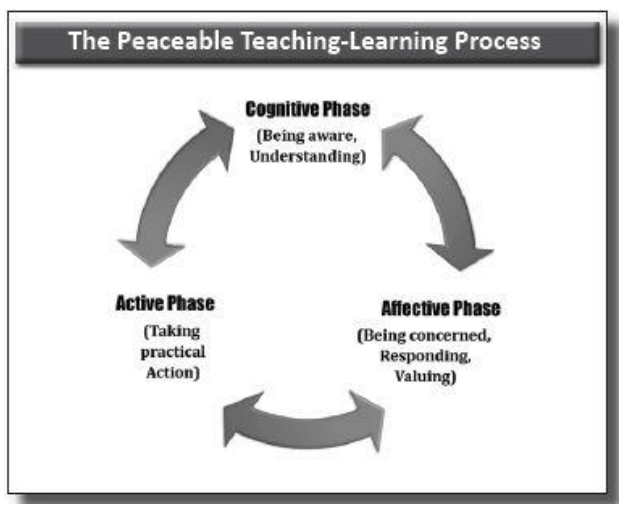

Gambar 2. Learning Process

Sumber: (Navarro-Castro \& NarioGalace, 2010, hlm. 29)

Siklus, sebagaimana digambarkan pada gambar 2, merupakan kunci kesinambungan antara penanaman prinsip kedamaian, melalui proses pendidikan dan relasi antar variabel yang membentuk manusia yang hendak dibentuk. Karenanya, berbagai dukungan untuk membentuk target tersebut tidak dapat diabaikan. Sebagai contoh, tidak mudah menanamkan prinsip perdamaian bila hanya terpaut dalam tekstual semata, sehingga mengasah rasa tidak bisa diabaikan, dan tentunya itu memerlukan sebuah tindakan untuk menyempurnakan rasa tersebut. Itu kembali pada sejauh mana pemahaman kita mengenai perdamaian dan serumit apa persoalan, konflik, dan kekerasan yang mesti dihadapi. Artinya, ruang kelas saja, untuk semua definisi tentangnya, tidak lah cukup. Tapi, itu bisa menjadi tempat, setelah keluarga, untuk proses pendidikan damai yang cukup efektif untuk dilakukan, misalnya perguruan tinggi.

Lantien dan Patti, (dalam Navarro-Castro \& Nario-Galace, 2010, hlm. 167), pernah menjelaskan ruang kelas yang dibangun dengan prinsip kedamaian atau peaceable classroom. Dalam hal ini, William Kreidler hadir sebagai pencetus konsep "ruang kelas yang damai" (peaceable classroom), di mana ia mulai menerapkan pertama kali di sekolah dasar. Pada saat itu, ia sebagai guru, memandang konflik yang terjadi di ruang kelas disebabkan oleh banyak faktor, seperti miskominukasi, pengucilan, ketidakmampuan menunjukan ekspresi pada umumnya, dan kurangnya kepedulian dan rasa hormat satu sama lain. Kehadiran peaceable classroom ini menjadi cerminan dari problem yang kerap ditemukan di instansi pendidikan, dan itu merupakan hal yang patut diwaspadai karena menjadi cikal bakal lahirnya konflik di masa depan akibat ketidakmampuan seseorang dalam menilai perbedaan. Navarro-Castro \& Nario-Galace (2010, hlm. 167) mengungkapkan, "A Peaceable classroom is characterized by affirmation, cooperation, communication, ahlmreciation for diversity, ahlmropriate expression of feelings and peaceful conflict resolution."

\section{Daya Kritis dan Kekuatan Pemahaman untuk Perdamaian dan Resolusi Konflik}

Pendidikan damai sendiri memusatkan perhatian kepada subjek, terlebih (calon) 
jurnalis dalam rangka memperluas pengetahuannya dan mengasah kemampuannya dalam mempertimbangkan dua kutub berlainan, tanpa mengabaikan sedikit pun kehadiran guru sebagai sumber alternatif nilai, selain dari buku dan adaptasi lingkungan. Webel dan Galtung (2007, hlm. 216) sendiri menyebutkan, "Peace education is concerned with developing pedagogies that enable learners to think in terms of complexities beyond the standard curricula on controversial issues that usually teach students to consider little more than the two major ohlmosing positions involved in the public discourse on the issues in question." Bahkan, pendidikan damai di sini mengizinkan setiap orang di dalamnya untuk melampaui batasan pemikiran yang umumnya terbatas pada kurikulum, memberi ruang kepada murid untuk bisa melihat persoalan dan konflik yang kompleks dengan sudut pandang yang luas dari setiap wacana atau problematika kontemporer lainnya, seperti konflik Palestina dan Israel yang kembali bentrok pada pertengahan bulan Mei 2021.

Tidak heran, umumnya lebih baik orang banyak "mengetahui" secara baik dan utuh, daripada sedikit dan tidak memadai. Jadi, jangan lah batasi diri dan pikiran terhadap satu hal atau bahkan kepada sesuatu yang hanya "menyenangkan diri" semata karena itu menutup kemungkinan memandang dunia yang luas, lebih buruk lagi menutup keran dialog dan interaksi antar manusia. Mungkin, ada benarnya juga bila Paulo Freire (2019, hlm. 86-87) berpandangan bahwa dialog yang sejati tidak akan ada jika tidak melibatkan pemikiran kritis-pemikiran yang melihat hubungan solidaritas tak terpisahkan antara dunia dan manusianya, sekaligus mengakui bahwa tidak ada dikotomi di antara keduanya- pemikiran yang melihat realitas sebagai proses, sebagai perubahan, bukan sebagai entitas yang statis-pemikiran yang tidak terpisah dari aksinya, namun tetap membenamkan diri dalam pikiran keduniaan tanpa takut akan resiko yang ada. Bila demikian adanya, maka banyak hal yang cukup membuat pandangan kita sulit menerima suatu hal di luar sana, apalagi bila ia (agak) terbuka hanya kepada kesenangannya saja dan sulit menerima fakta yang ada.

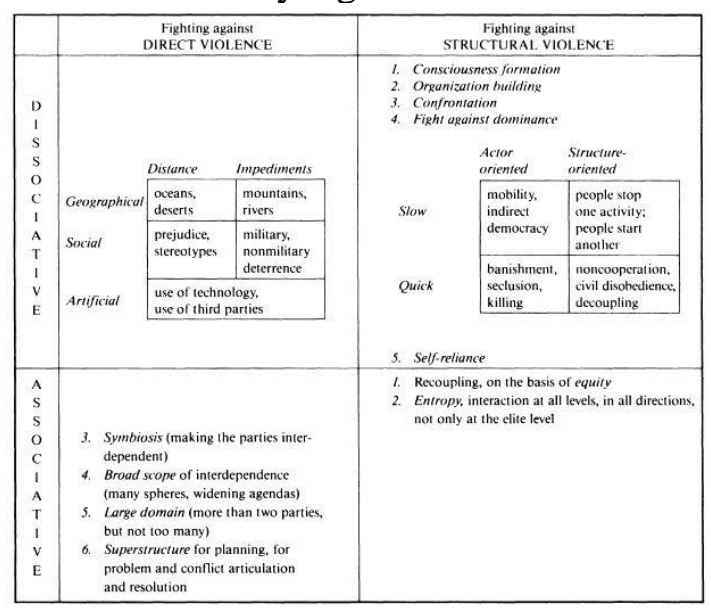

\section{Gambar 3. Skema "Bertarung demi Kedamaian dan Pertarungan Melawan Kekerasan}

Sumber: (Galtung, 1985, hlm. 150)

Sikap kritis yang menjadi padanan utama dalam pemikiran dialektis Pauolo Freire bisa menjadi referensi. Guna memperkaya konten dalam peace education, dan tentunya mengasah daya kritis, barangkali model yang dikemukakan oleh Johan Galtung di gambar 3 di atas bisa menjadi referensi yang baik untuk digunakan. Dalam ilustrasi tersebut, ia sedikit menggambarkan, bagaimana upaya seseorang untuk memposisikan dan menghadapi dua kemungkinan persoalan, yaitu perdamaian dan kekerasan. Dalam hal ini, salah satu konsep terkenal dari Johan Galtung mengenai kekerasan langsung dan struktural dapat dihadapi 
dengan berbagai cara, misalnya kekerasan struktural yang meliputi eksploitasi, penetrasi, fragmentasi, marginalisasi; dan kekerasan langsung mencakup melukai, merobek, menusuk, menghancurkan, membakar, meledakan, dll, dapat dilawan melalui cara disosiatif maupun asosiatif. Misalnya, memisahkan diri dari kelompok, partai, atau struktur penindasan, atau mungkin menghancurkan struktur palsu melalui jalan revolusi atau reformasi, sedangkan cara lainnya dengan metode asosiatif bisa dikembangkan dengan keterlibatan dalam kegiatan, pesta bersama, membangun struktur yang benar, dan lainnya.

Dalam proses moderasi, pendidikan damai perlu dihidupkan dengan cara yang dialogis, di mana pihak-pihak cukup terbuka untuk saling memahami satu sama lain, tanpa sekat, memungkinkan berbagai pihak untuk bisa mengambil pelajaran dan mengasah kebijaksanaan dalam bersikap terhadap perbedaan. Paulo Freire (2019) pernah menyinggung proses dialogis ini, di mana ia melihat bahwa, "Dialogical learning is characterized by codification and de-codification processes in which the world of practice in everyday life is put on the agenda for discussion in the educational interactions." Dengan begitu, kita asumsikan bahwa sejatinya pembelajaran yang dialogis merupakan proses untuk "membongkar" atau sebaliknya, di mana itu merupakan cara yang baik untuk menghidupkan interaksi. Bagaimana pun, guna membangun komunikasi dalam kehidupan praktis, keterbukaan dan keluasan pengetahuan menjadi jembatan untuk saling menghargai satu sama lain. Secara sederhana, tanpa dialog, tidak akan ada komunikasi, dan tanpa komunikasi tidak akan ada pendidikan yang sejati (Freire, 2019, hlm. 87-88). Maka, jurnalisme sebagai ladang komunikasi, pendidikan dan kumpulan wacana akan menjadi sorotan utama, dalam hal ini, bagaimana ia menjadi penebar "benih", entah itu informasi atau sekadar sensasi bahkan mungkin provokasi, yang akan berdampak besar pada wajah kehidupan berbangsa dan bernegara.

\section{Peace Education dalam Membentuk Watak Jurnalisme yang Damai}

Sejauh ini, konsepsi peace building (membangun kedamaian) sebagai mekanisme penggerak peace education tidak jauh berbeda dengan pengimplementasiannya nanti, yaitu pengejawantahan dari upaya membongkar seberkas permasalahan kompleks yang menjadi cikal bakal dari adanya konflik dalam suatu persoalan. Tidak heran, bila peace building harus mengandalkan tidak hanya pemahaman yang mendalam, tetapi juga daya kritis yang kuat. Simon Fisher, dkk (dalam Sujibto, 2015, (hlm. 278) menegaskan bila intinya basis gerakan peace building bermuara pada upaya mengupas konteks dan tingkah laku yang akan menimbulkan tindak kekerasan, seperti ketidakadilan aksesibilitas, diskriminasi, prasangka, ketidakpercayaan, ketakutan, dan permusuhan antara kelompok; bukan berkaitan dengan perilaku konflik itu sendiri. Kehadiran peace education sebagai bagian dari upaya membangun kedamaian pun akan semakin nampak dalam memandang sebuah jurnalisme sebagai kekuatan utama di era informasi seperti sekarang, karena melalui itu pula lah daya kritis seseorang diuji, termasuk daya cipta jurnalistik yang akan membawa pada sebagian besar perubahan, entah menuju ke arah yang lebih baik atau menjadi sumber petaka (baru).

Sedari awal telah diungkapkan, bahwa salah satu kekuatan di era informasi ini perlu untuk diwaspadai, yaitu jurnalisme. Sebagai bagian yang tidak terpisahkan dari hak manusia akan informasi dan 
kemerdekaan berpikir, jurnalisme, kepenulisan, dan hal-hal yang berkaitan dengannya tidak bisa dielakkan. Mungkin, kita teringat dengan optimisme peace education dalam membentuk kebijaksanaan dan memperluas cakrawala pengetahuan dalam menghadapi masalah konflik, kekerasan dan perdamaian. Namun, apakah itu bisa menjamin seorang "jurnalis" untuk mendamaikan suasana?

Sejauh ini, kita tidak akan membatasi jurnalisme dalam perspektif profesional semata, melainkan sesuatu yang dekat dengan kita, semisal berbagi informasi. Kita beranggapan bahwa apapun informasi yang tersampaikan, nyatanya apa adanya dan "baik-baik saja". Tetapi, bila itu diletakan pada masa ini, cukup naif untuk bisa melepaskannya dari berbagai variabel di dalamnya, termasuk ketidaktahuan. Di sini, pendidikan damai sudah berada di luar kuasanya, karena memang jurnalisme berada di luar dimensi. Tetapi, paling tidak seorang jurnalis yang telah dibentuk menjadi manusia berprinsip "damai", bisa meletakan dan mengambil porsi sesuai hati nuraninya. Hal itu jarang ditemukan, paling tidak untuk saat ini, karena beberapa orang dalam lingkaran media massa, secara dilematis, harus dibenturkan dengan "profesionalisme", hati nurani, dan egoisme. Tidak mengherankan, beberapa karya jurnalistik tidak mampu memberikan kualitas yang memadai bagi pembaca, namun hanya sekadar "berbagi" sensasi semata atau spesialis dalam menggoreng isu yang tidak karuan dan berpotensi merusak pilar perdamaian yang telah dibangun.

Jadi, individu (subjek) punya peran besar dalam tindakan dan dampak sosial yang terjadi. Melalui jurnalisme dan karyanya, semua akan menentukan kondisi kebersamaan di lapangan. Harapannya memang berbunyi demikian, bahwa peace education mengasah daya rasa dari individu, terlebih (wajib) bagi jurnalis di masa depan. Dengan memahami subjek sebagai individu, termasuk di dalamnya hubungan antar subjek, kelompok, dan lingkungan, untuk perannya dalam membangun kedamaian, akan sangat berarti bagi berkembangnya peace education. Itu juga cukup memberi kekuatan untuk mewujudkan peace building yang menjadi fondasi terbentuknya upaya mewujudkan perdamaian. Weber (dalam Sujibto, 2015, hlm. 280), dalam perspektif methodology of social science-nya, menggambarkan arti subjektif sebagai komponen untuk mengupas "atom-atom" tindakan sosial yang lahir dari interest personal dan tindakan subjektif secara khusus karena otoritas tindakan individu sangat berperan dalam mengartikulasikan tindakan sosial yang pada akhirnya tindakan individu tersebut akan membentuk, dalam istilah Emile Durkheim, realisme sosial atau fakta sosial yang bisa ditandai secara riil. Tidak heran, beberapa pandangan awal menilai bahwa budaya damai dibentuk justru dari tindakan subjek itu sendiri, di mana itu dilandaskan dari metode berpikir yang "menentramkan" berbagai pihak. Dan, hal itu tidak cukup kuat bila semua tanggungjawab itu diberikan pada subjek individu tersebut. Orang lain, lingkungan, dan institusi berbagi peran dalam membentuk insan yang berpikiran damai. Jadi, konten pendidikan damai tidak melulu berbicara perdamaian, tapi harus memandang itu dari berbagai sudut pandangan, keilmuan, dan keadaan.

Beberapa konten pembelajaran layak untuk diimplementasikan, semisal substansi Hak Asasi Manusia (HAM) yang terintegrasi dengan beberapa pelajaran seperti civic education (pendidikan kewarganegaraan), pendidikan agama atau mungkin liberal art, ilmu pengetahuan sosial, dan lain sebagainya. Sebagai contoh, beberapa 
aspek-aspek yang dikembangkan pada program peace education, diantaranya muatan berhubungan dengan kedamaian dan anti kekerasan (peace and nonviolence), HAM (human rights), demokrasi, toleransi, pemahaman antar bangsa dan antar budaya (international and intercultural understanding) atau kebangsaan, dan yang cukup vital seperti pemahaman perbedaan budaya dan bahasa (cultural and linguistic diversity) yang menjadi sorotan bila ingin mewujudkan peace building (Machali, 2013, hlm. 44). Dengan begitu, seorang jurnalis akan terasah dan terus mengembangkan pengetahuannya, begitu juga perasaan dan pengambilan keputusannya, termasuk bagaimana seorang jurnalis dapat membawa perdamaian itu sendiri melalui karyanya. Terdapat satu hal yang turut dipertimbangkan, terlebih dalam upaya "pemulihan" perdamaian, yaitu bagaimana mengambil alih konflik dan mentransformasikannya ke dalam resolusi untuk mengakhiri kanker dalam kehidupan yang damai.

Upaya transformatif menuju kedamaian yang didengung-dengungkan itu, sejatinya cukup memberikan tamparan kepada inkonsistensi dan ironi bagi jurnalis dalam media massa. Dengan begitu, kita bisa mengasumsikan bahwa memang jurnalis sebagai informan kepada masyarakat, secara transformatif dan progresif, harus membawa tanggung jawab besar dalam terciptanya harmoni atau ketidakadilan di masyarakat. Tidak salah juga, bila peace education tetap berfokus dalam membentuk manusia yang bijak dan berwawasan luas, agar mampu memberikan solusi yang tepat dalam menjaga kedamaian melalui jurnalisme damai dan sehat atau menjadi bagian dalam upaya mendamaikan dan "mediator" konflik dua atau beberapa bangsa atau negara.

\section{Tujuan Tiada Akhir Peace Education}

Demikian apa yang disebutkan sebelumnya, kita memerlukan suatu konten khusus dalam pendidikan damai yang mengakomodasi lahirnya resolusi dan pemikiran-pemikiran progresif guna pemulihan, termasuk dalam konflik sekalipun, yaitu yang dikenal sebagai studi perdamaian untuk transformasi konflik. Aji dan Indrawan (2019, hlm. 78), dalam hal ini berpandangan bahwa transformasi konflik harus mendapat perhatian yang serius. Mereka melanjutkan, jika transformasi konflik merupakan salah satu metode resolusi atau penyelesaian konflik yang menjadi bagian dari kajian studi perdamaian. Dengan begitu, pendidikan damai yang dibuat akan terasa lebih lengkap dengan dipersenjatai oleh kemamuan untuk mencegah dan memulihkan keadaan ketika dan pasca konflik. Metode resolusi semacam ini juga memberikan kita pengetahuan dan mengasah kemampuan responsif kita ketika berhadapan dengan konflik yang cenderung kompleks dan destruktif. Dalam metode ini juga, posisi kita dalam melihat persoalan menjadi titik penekanan yang tidak bisa diabaikan, katakan saja bagaimana kita memposisikan diri dalam konflik, apakah netral atau harus mempertaruhkan dasar keyakinan pada suatu hal tertentu.

Kita tidak bisa meremehkan kehadiran konflik barang sekecil apapun. Bagaimana pun, konflik adalah reaksi dari dari bentuk egoisme manusia terhadap ketidaksesuaian apa yang hendak dicapainya. Maka, jangan berpikir bahwa konflik tidak melibatkan apapun - sejauh apa yang dimaksud "segala hal"-yang melingkupi sudut-sudut kemanusiaan. Conflict touches everything in us, our feelings, our thoughts. Conflicts demand of us everything we have to offer. If not, our emotions will easily be expressed as violence, insulting the basic needs of others, as verbal violence, physical violence, or both (Galtung, 2004, hlm. 4). 
Apapun bentuk peace education yang melatarbelakangi terbentuknya perdamaian abadi, pada hakikatnya model ini punya satu hal implisit yang harus tetap konsisten hadir sebagai bagian dari upaya rekonsiliasi, yaitu memandang dunia dengan cara yang lebih baik. Thapa, dkk., (2010, hlm. 17) menilai, bahwa pendidikan damai ini harus berada di setiap kondisi, tanpa kecuali, "When societies are involved in intractable conflict, the objective of peace education should be to advance and facilitate peace making and reconciliation. It aims to construct society members (including students) worldview (i.e. their values, beliefs, attitudes, emotions, motivations, skills and patterns of behaviour) in a way that facilitates conflict resolution and the peace process and prepares them to live in an era of peace and reconciliation."

Keberhasil sederhana yang patut diperhitungkan dalam membangun budaya damai, seperti yang diharapkan dari peace education adalah meningkatnya rasa kemanusiaan dan kemampuan mengasah jiwa yang lebih humanis, salah satunya adalah kemampuan untuk mengakui bahwa dirinya (pun) memiliki empati dan kekecewaan diri sebagai konsekuensi dalam tindakan keliru. Bila kita cermati, kemampuan yang dimaksud adalah kemampuan memberikan rasa maafnya, kepada dirinya ataupun orang lain. D. R. Enright dan C. T. Coyle (dalam Suud, 2018, hlm. 710) menjelaskan bahwa beberapa hal yang turut mempengaruhi seseorang dalam memberikan "rasa maafnya", ialah besarnya empati, penilaian terhadap orang lain, tingkat rasa sakit seseorang, karakteristik kepribadian seseorang, kualitas hubungan interpersonal, kualitas permintaan maaf, dan kondisi sosial kognitif seseorang. Dalam Al. Qur'an surat Asy. Syura ayat 39-40, Allah SWT berfirman: "Dan (bagi) orang-orang yang apabila mereka diperlakukan dengan zalim mereka membela diri. Dan balasan suatu kejahatan adalah kejahatan yang serupa, maka barang siapa memaafkan dan berbuat baik maka pahalanya atas (tanggungan) Allah. Sesungguhnya Dia tidak menyukai orang-orang yang zalim. “

Ujian terbesar dari kehadiran konflik adalah keinginan "memaafkan" untuk menghentikan lingkaran setan dendam, iri, dengki dan sebagainya. Memberi maaf artinya menghilangkan rasa dendam dan menghilangkan kemarahan, kemampuan memberikan maaf dapat dilakukan jika seseorang memiliki kelebihan untuk mampu menghilangkan keburukan (dendam) pada dirinya (Suud, 2018, hlm. 705). Dalam hal ini, pendidikan perdamaian bisa menjadi kunci untuk mengasah kebijaksanaan seperti itu, dan mungkin perlu waktu untuk bisa menyesuaikan diri. Pendidikan perdamaian dipahami secara umum bertujuan untuk menawarkan kesempatan untuk mengembangkan keterampilan, pengetahuan dan nilai-nilai yang diperlukan untuk praktek resolusi konflik, komunikasi dan kerjasama dalam kaitannya dengan masalah perdamaian, perang, kekerasan, konflik dan ketidakadilan. Pendidikan perdamaian dapat dilaksanakan dalam masyarakat yang berada dalam konflik, masyarakat pasca konflik dan masyarakat yang stabil untuk mencapai penyelesaian masalah secara damai. (Thapa, dkk., 2010, hlm. 17)

Uri Savir (dalam Aji \& Indrawan, 2019, hlm. 80) menyebutkan bahwa perdamaian hanya dapat dicapai melalui kerja sama dan sikap positif di antara masyarakat negara-negara yang sedang berkonflik. Tidak salah bila perdamaian sendiri sering kali diungkapkan setara sebagai "perjuangan" Teringat kata-kata menarik dalam sebuah meme yang kerap 
menyebutkan, "Peace was never an option", dan itu bukan bualan semata. Sekalipun terdapat dimensi politik, khususnya dalam struktur sosial dan budaya yang melatarbelakangi, baik perdamaian maupun konflik, tetapi sesungguhnya kekuatan utama untuk menciptakan perdamaian justru lahir dan berkembang melalui keterlibatan individu dan masyarakat madani (civil society) dan bukanlah pada pemerintah, institusi atau lembaga manapun. Variabel itu hanyalah penyokong, namun bukan esensi utama.

\section{SIMPULAN DAN SARAN}

Peace building memang cukup menjanjikan. Sejauh ini, cara ini dipandang efektif untuk menghasilkan wacana-wacana yang mampu meminimalisir konflik karena berhasil membendung pemikiran-pemikiran destrukftif dari para pelajar, termasuk pendidik yang menjadi sumber nilai perdamaian itu. Meskipun begitu, keberhati-hatian dalam mengungkapkan "damai" secara literatur maupun perspektif lainnya harus diperhitungkan. Barangkali, beberapa konsepsi perdamaian dalam pendidikan damai, justru memberikan hasil yang tidak terduga, bahkan mungkin menghasilkan model kekerasan baru yang lebih canggih dari pada sebelumnya. Itulah kedamaian palsu.

Peace education menjadi cara yang baik untuk menanamkan nilai-nilai perdamaian, terlepas di mana pun dan kapan pun, meski kita tidak bisa mengingkari bahwa institusi pendidikan menjadi salah satu instrumen yang mampu menghasilkan hal seperti itu. Walaupun, kita tidak sepenuhnya berharap institusi pendidikan hingga perguruan tinggi mampu memberikan $100 \%$ prinsip kedamaian, karena dalam beberapa kasus, justru di sana lah menjadi sarang kekerasan budaya, misalnya bullying yang cukup mengganggu proses pendidikan damai. Oleh karena itu, hal yang semestinya diperhatikan adalah keberadaan kedamaian yang ada pada diri individu tersebut.

Dengan melahirkan banyak insan yang tidak hanya mampu secara intelektual tapi juga rasa, maka selangkah lebih baik untuk menghasilkan harmoni, terlebih di bidang komunikasi. Dalam hal ini, jurnalis hadir sebagai kekuatan penting di era informasi, kerap kali dihadapkan secara dilematis antara kehidupan harmonis, mencari sensai, atau peruntungan untuk mengungkapkan "kebenaran" tanpa memahami masa depan yang tidak bisa didamaikan. Dengan setitik harapan dari peace education, para jurnalis pemberi informasi, penyebar, dan lainnya, paling tidak bisa menghasilkan suatu kebijaksanaan yang dapat mendukung kebenaran tanpa konflik yang berarti atau mungkin menjadi mediator untuk mendamaikan pihak-pihak yang terlibat di dalamnya. Dengan begitu, jurnalisme damai mendambakan orang-orang yang mampu menjaga keharmonisan dan kehangatan masyarakat dan warga negara.

Pendidikan kedamaian memberikan satu jalan untuk mengembangkan potensi kebijaksanaan seseorang, sekalipun yang dimaksud tidak sebatas pada ruang kelas yang dibentuk se-peaceable mungkin. Dengan begitu, orang akan senantiasa belajar untuk mengasah kemampuan dirinya setiap waktu dan di manapun, khususnya bila dihadapkan dengan konflik yang cukup rumit dan kompleks. Barangkali, tidak semua bisa terakomodir, namun melalui salah satu metodenya, peace education, menjadi cara untuk mempertajam dan memperluas cakrawala pengetahuan mengenai dunia yang beragam dan bagaimana orangorang di dalamnya mampu mengelola perbedaan itu. 


\section{DAFTAR PUSTAKA}

Aji, M. P. \& Indrawan, J., 2019. Memahami Studi Perdamaian sebagai Bagian dari Ilmu Hubungan Internasional. Jurnal Pertahanan \& Bela Negara, IX(3), hlm. 65-84.

Andarini, R. S., 2014. Jurnalisme Damai dalam Pemberitaan Ahmadiyah pada Harian Jawa Pos. Jurnal Interaksi, III(1), hlm. 85-93.

Anon., 2020. Moderasi Beragama dalam Ruang Digital: Studi Pengarusutamaan Moderasi Beragama di Perguruan Tinggi Keagamaan Islam Negeri. Jurnal Bimas Islam, XIII(1), hlm. 1-22.

Ansori, Y. Z., 2019. Islam dan Pendidikan Multikultural. Jurnal Cakrawala Pendas, V(2), hlm. 110-115.

Atmanto, N. E., 2017. Pendidikan Damai Melalui Pendidikan Agama pada Sekolah Menengah Atas di Daerah Pasca Konflik. Jurnal SMaRT, III(2), hlm. 155168.

Campbell, H. A., 2010. When Religion Meets New Media. 1st ed. New York: Routledge.

Creswell, J. W., 2014. Research Design: Pendekatan Kualitatif, Kuantitatif, dan Campuran. 4th ed. Yogyakarta: SAGE Publication, Inc.

Dawson, C., 2002. Practical Research Methods: A User-Friendly Guide to Mastering Research Techniques and Projects. 1st ed. Oxford: How To Books Ltd.

Eriyanti, L. D., 2017. Pemikiran Johan Galtung tentang Kekerasan dalam Perspektif Feminisme.
Jurnal Hubungan Internasional, VI(1), hlm. 1-11.

Espitia, F., Sánchez-Torres, J. M. \& Galvis-Lista, E., 2016. Systematic Literature Review of the Implementation of Knowledge Codification Process. Passau, European Conference Knowledge Management.

Galtung, J., 1981. Social Cosmology and the Concept of Peace. Journal of Peace Research: Special Issue on Theories of Peace, XVIII(2), hlm. 183-199.

Galtung, J., 1985. Twenty-Five Years of Peace Research: Ten Challenges and Some Responses. Journal of Peace Research, XXII(2), hlm. 141-158.

Galtung, J., 2004. Transcend and Transform: An Introduction to Conflict Work. 1st ed. London: Pluto Press.

Indonesiabaik.id, 2017. Jurnalisme Damai Untuk Rekonsilasi. [Online] Didapat dari: http://indonesiabaik.id/infografis /jurnalisme-damai-untukrekonsilasi [Diakses 7 Mei 2021].

Juditha, C., 2016. Jurnalisme Damai dalam Berita Konflik Agama Tolikara di Tempo.co. Jurnal Penelitian Komunikasi dan Opini Publik, XX(2), hlm. 93-110.

Kementerian Agama RI , 2019. 2019, Indeks Kerukunan Umat Meningkat. [Online] Didapat dari: https://kemenag.go.id/berita/rea d/512322/2019--indekskerukunan-umat-meningkat [Diakses 7 Mei 2021].

Lembaga Ketahanan Nasional RI, 2021. 
Menteri Agama: Moderasi Beragama Menjadi Sangat Penting. [Online] Didapat dari: http://www.lemhannas.go.id/ind ex.php/berita/beritautama/1013-menteri-agamamoderasi-beragama-menjadisangat-penting [Diakses 7 Mei 2021].

Machali, I., 2013. Peace Education dan Deradikalisasi Agama. Jurnal Pendidikan Islam, II(1), hlm. 4164.

Nahdlatul Ulama, 2019. Penemuan Enam Jenis Konflik Keagamaan di Indonesia. [Online] Didapat dari:

https://www.nu.or.id/post/read/ 114890/penemuan-enam-jeniskonflik-keagamaan-diindonesia [Diakses 7 Mei 2021].

Navarro-Castro, L. \& Nario-Galace, J., 2010. Peace Education: A Pathway to a Culture of Peace. 2nd ed. Quezon City: Center for Peace Education, Miriam College.

Soekanto, S., 2006. Sosiologi: Suatu Pengantar. 7th ed. Jakarta: Rajawali Pers.

Sugiyono, 2013. Metode Penelitian Kuantitatif, Kualitatif, dan R\&D. 19th ed. Bandung: CV Alfabeta.

Sujibto, B., 2015. Spirit Peacebuilding Melalui Komunitas Pemuda di Yogyakarta. Sosiologi Reflektif, X(1), hlm. 273-302.

Supriyadi, 2016. Community of Practitioners: Solusi Alternatif Berbagi Pengetahuan Antar Pustakawan. Lentera Pustaka, II(2), hlm. 83-93.

Suud, F. M., 2018. Pendidikan Kedamaian di Era Digital
(Telaah Model Forgiveness dalam Psikologi Islam). FIKROTUNA: Jurnal Pendidikan dan Manajemen Islam, VII(1), hlm. 694-716.

Thapa, M., Dhungana, R. K., Mahalingam, B. \& Conilleau, J., 2010. Peace by Piece: Mainstreaming Peace Education. Sweden: Save the Children Sweden.

Universitas Islam Negeri Syarif Hidayatullah Jakarta, 2021. Rilis Temuan Survei, HLMIM Paparkan Potret Toleransi Beragama di Universitas. [Online] Didapat dari: https://hlmim.uinjkt.ac.id/2021/ 03/01/rilis-temuan-surveihlmim-paparkan-potrettoleransi-beragama-diuniversitas/ [Diakses 7 Mei 2021].

Webel, C. \& Galtung, J., 2007. Handbook of Peace and Conflict Studies. 1st ed. New York: Routledge.

Wertz, F. J. et al., 2011. Five Ways of Doing Qualitative Analysis: Phenomenological Psychology, Grounded Theory, Discourse Analysis, Narrative Research, and Intuitive Inquiry. New York: The Guilford Press.

Zed, M., 2018. Metode Penelitian Kepustakaan. 5th ed. Jakarta : Yayasan Pustaka Obor Indonesia. 